\title{
The current status of Argentine stem weevil (Listronotus bonariensis) as a pest in the North Island of New Zealand
}

\author{
A.J. Popay ${ }^{1}$, M.R. McNeill' ${ }^{2}$ S.L. Goldson ${ }^{2}$ and C.M. Ferguson ${ }^{3}$ \\ ${ }^{1}$ AgResearch, Ruakura Research Centre, Private Bag 3123, Hamilton, New Zealand \\ ${ }^{2}$ AgResearch, Lincoln Research Centre, Private Bag 4749, Christchurch, New Zealand \\ ${ }^{3}$ AgResearch, Invermay Agricultural Centre, Private Bag 50034, Mosgiel, New Zealand \\ Corresponding author: alison.popay@agresearch.co.nz
}

\begin{abstract}
Recent sampling in Waikato and Taranaki shows that Argentine stem weevil (Listronotus bonariensis) can still cause major damage to susceptible ryegrass pastures despite the introduction of the parasitoid, Microctonus hyperodae, in 1991. Percentage of tillers with L. bonariensis larval damage in diploid and tetraploid perennial ryegrass and Italian ryegrass in January and February were between $11 \%$ and $68 \%$. High egg numbers were noted on occasion. Although there is evidence that M. hyperodae reduces host populations, parasitism levels vary considerably between years in Canterbury and are low in Otago and Southland where high populations of L. bonariensis have recently been recorded. Factors that may be lessening the impact of M. hyperodae are considered. These include asynchronous generations of the parasitoid and its host, host behavioural adaptations, compensatory oviposition and inhibition of flight in parasitised individuals leading to low levels of parasitism in new pastures.
\end{abstract}

Keywords ryegrass, damage, parasitoid, Microctonus hyperodae, endophyte, Neotyphodium lolii.

\section{INTRODUCTION}

Argentine stem weevil (Listronotus bonariensis (Kuschel)) has been a serious pest of New Zealand Graminae in improved pasture for more than 100 years. When unsuppressed, this species was estimated to cause losses to the pastoral sector of NZ\$78-251M annually (e.g. Prestidge et al. 1991). The parasitoid Microctonus hyperodae Loan (Hymenoptera: Braconidae) was successfully introduced in 1991 (Goldson et al. 1993), with the expectation that biological control in conjunction with endophyte-induced plant resistance would form part of an integrated pest management (IPM) approach to controlling L. bonariensis. Microctonus hyperodae attacks the adult stage, sterilising female weevils and eventually killing them after which the mature larva emerges to pupate in the litter. Between 1992 and 1998, further releases saw the widespread distribution of the parasitoid in both North and South Islands (McNeill et al. 2002) and through ongoing natural dispersal from these releases, the parasitoid can be considered to be present in all pastures where L. bonariensis is present.

Early evidence after the introduction of $M$. hyperodae indicated that $L$. bonariensis populations and their effects were reduced in areas where this insect had previously caused repeated severe damage. Barker \& Addison (2006) noted such impacts in Waikato and Goldson et al. (1998) in Canterbury. On this basis, it has 
been unexpected to find evidence from pastures sampled in Waikato and coastal Taranaki over the last 4 years showing that $L$. bonariensis still causes significant damage at least on occasions. This information is interpreted in terms of information on the population dynamics of L. bonariensis, fluctuations in parasitism levels and the ecology of the weevil.

\section{METHODS}

Tiller sampling was carried out near Hamilton over 4 years on a trial at DairyNZ and 2 years on a trial at Gordonton. In addition, farmers' paddocks where severe L. bonariensis damage had been reported were sampled in coastal Taranaki in 2009 and near Morrinsville in 2010.

\section{Listronotus bonariensis damage estimates}

Tillers taken for $L$. bonariensis damage assessments were always cut below the base of the pseudostem. Tillers were scored for adult feeding damage on leaf blades on either a scale of $0-5$, where $0=$ no feeding and $5=$ extensive feeding along the leaf blades (Adult Feeding Score, AFS), or by approximate counts of feeding scars on the leaf and incorporating scar size into the estimate by rating a large scar either a 2 or a 3 to obtain a total feeding score/leaf. The pseudostem was examined for the presence of eggs and larval damage. Any larval damage was scored as being minor (small amount of chewing damage on external surface of the tiller), moderate (larva had penetrated the tiller and some mining of central pseudostem was apparent) or major (larva had extensively mined a tiller or penetrated the meristem).

\section{DairyNZ Trial 2006-2009}

This trial, conducted on Scott Farm at Newstead near Hamilton, compared three endophyte (Neotyphodium lolii) strains and endophytefree perennial ryegrass (Lolium perenne) cv. 'Commando' for their effects on cow health, agronomic characteristics and insect infestations. The trial was planted in autumn 2005 and L. bonariensis damage was monitored annually on the trial between 2006 and 2008 (Popay \& Thom
2009). Data are presented here for the endophytefree paddocks only for that period. In 2009 on 14 January, two endophyte-free paddocks used to graze cows prior to them grazing the trial were sampled by randomly cutting 20 clumps of tillers. These paddocks had been endophyte-free since the original trial was planted in 2005, and had been re-drilled in April 2008. In the laboratory, five tillers were sampled without conscious bias from each clump and assessed as described for L. bonariensis adult feeding, oviposition and larval damage.

\section{'Bealey' NEA2 2010}

Two paddocks on one farm and two on a nearby property close to Morrinsville were sampled on 22 February 2010. These paddocks had been sown in tetraploid perennial ryegrass cv. 'Bealey' NEA2, two in autumn 2008 (Paddocks A2 and B2) and two others in autumn 2009 (Paddocks A1 and B1). From each paddock, 25 clumps of tillers were taken and, from these, four live tillers were sampled at random and checked for L. bonariensis adult feeding, eggs and larval damage. A further 25 dead tillers sampled at random from the tiller clumps taken in Paddocks $\mathrm{A} 1$ and $\mathrm{B} 1$ were also examined for larval damage. A random sample of 100 tillers from Paddocks $\mathrm{A} 1$ and B1, and 50 tillers from Paddocks A2 and B2 were tested for the presence of endophyte by immunoblotting.

\section{Italian ryegrass trial, 2010-2011, Gordonton}

In this trial, $12 \times 3 \mathrm{~m}$ plots of Italian ryegrass (Lolium multiflorum) cv. 'Status', without endophyte or infected with AR1 or AR37 were sown in autumn 2009. For each endophyte treatment, seed had been either treated with Superstrike or left untreated. Treatments were replicated four times. All plots were sampled for L. bonariensis in January 2010 by taking 50 tillers at random from each plot. Pooled data (treated and untreated) are presented here only for the endophyte-free plots. In autumn 2010, endophyte-free ryegrass plots were re-drilled with the same treatment and these were sampled in January 2011 by taking 25 clumps of tillers 
from each replicate. Samples were combined for replicates 1 and 2 and for replicates 3 and 4 . From each of these combined samples 100 tillers were checked for L. bonariensis larval damage.

\section{Farms in Taranaki}

Tiller samples were submitted to AgResearch in mid March 2009 after two farmers near Patea in southern Taranaki reported damage in tetraploid ryegrasses cv. 'Banquet II' and 'Quartet II'. The samples were comprised of live and dead tillers from six paddocks on one farm and three on another. Where possible 15 live and 15 dead tillers were examined for $L$. bonariensis larval damage from each paddock sampled but in some cases either dead or live tillers only were present. Paddocks were classed as being 'healthy, recovering or very poor'. Only dead plant material was present in samples from 'very poor' paddocks and only live material in 'healthy'. Between 17 and 39 live tillers taken from each of the 'recovering' and 'healthy' paddocks were checked for endophyte (strain Endo5) by immunoblot.

\section{RESULTS}

\section{DairyNZ Trial}

The percentage of tillers with larval damage in the endophyte-free paddocks in January of each year varied between a low of $11 \%$ in 2007 to $50 \%$ in one paddock in 2009 (Table 1). For the six paddocks sampled each year, the range in percent L. bonariensis larval damage varied between 15$40 \%$ in $2006,5-24 \%$ in 2007 and $10-30 \%$ in 2008. The majority of tillers with larval damage were severely or moderately damaged. Adult feeding scores and oviposition were generally low.

Table 1 Listronotus bonariensis adult feeding scores (AFS), number of eggs laid, percentage of tillers with larval damage (\%LD) and the percentage of damaged tillers classed as being moderately and severely damaged in ryegrass samples taken in the Waikato between 2006 and 2011.

\begin{tabular}{|c|c|c|c|c|c|}
\hline & Sample date & AFS/Tiller ${ }^{1}$ & $\begin{array}{c}\text { Eggs/100 } \\
\text { tillers } \\
\end{array}$ & $\% \mathrm{LD}$ & $\begin{array}{c}\text { \% Mod and } \\
\text { Severe }\end{array}$ \\
\hline \multicolumn{6}{|l|}{ DairyNZ trial } \\
\hline 6 trial paddocks ${ }^{2}$ & 12 Jan 06 & 0.27 & 0.6 & 25 & 70 \\
\hline 6 trial paddocks ${ }^{2}$ & 18 Jan 07 & 0.06 & 0 & 11 & 66 \\
\hline 6 trial paddocks ${ }^{2}$ & 15 Jan 08 & 0.46 & 2.7 & 20 & 80 \\
\hline Paddock A & \multirow{2}{*}{14 Jan 09} & $\mathrm{ND}^{3}$ & 2 & 39 & 74 \\
\hline Paddock B & & $\mathrm{ND}$ & 7 & 50 & 78 \\
\hline \multicolumn{6}{|l|}{ 'Bealey' paddocks } \\
\hline Paddock A1 & \multirow{4}{*}{22 Feb 10} & 7.7 & 13 & 50 & 68 \\
\hline Paddock A2 & & 2.8 & 6 & 18 & 50 \\
\hline Paddock B1 & & 5.7 & 9 & 48 & 81 \\
\hline Paddock B2 & & 0.7 & 0 & 23 & 83 \\
\hline \multicolumn{6}{|c|}{ Italian ryegrass trial } \\
\hline All nil plots & $25 \operatorname{Jan} 10$ & 2.0 & 14 & 26 & 77 \\
\hline All nil plots & 20 Jan 11 & ND & ND & 68 & 96 \\
\hline
\end{tabular}

${ }^{1}$ Adult feeding based on a scale of 0-5 for DairyNZ trial and on counts of feeding scars for 'Bealey' paddocks and Italian ryegrass trial.

${ }^{2}$ Adult feeding score and larval damage data presented in Popay \& Thom (2009).

${ }^{3} \mathrm{ND}=$ not determined 


\section{'Bealey' paddocks}

The percent endophyte infection levels in these paddocks were: A1 35\%; A2 72\%; B1 28\%; B2 $82 \%$. The 1-year-old paddocks $\mathrm{A} 1$ and $\mathrm{B} 1$ were visibly damaged with considerable pasture thinning, poor plant growth and many dead tillers. Adult feeding scores, number of eggs and the amount of larval damage were high in these pastures (Table 1). The majority of tillers with damage had been moderately or severely damaged. In addition, $88 \%$ of the 25 dead tillers examined from each of these paddocks had been killed by $L$. bonariensis larvae. The 2-year-old pastures had low densities of ryegrass with B2 in particular comprised mostly of weedy summer grasses. Listronotus bonariensis larval damage in these was much lower than in the 1-year-old pastures.

\section{Italian ryegrass trial}

The larval damage in the first year of this trial in 2010 was moderate but a high number of eggs was found (Table 1). When sampled the following year after the ryegrass had been redrilled in autumn 2010, severe damage to the endophyte-free plots was apparent with a very high proportion of tillers being damaged by larvae and the vast majority of those severely damaged.

\section{Farms in Taranaki}

For the nine paddocks sampled, three were each categorised as being healthy, recovering or poor. There was a high incidence of endophyte in live tillers taken from recovering and healthy paddocks (mean 95\%, $\mathrm{n}=174$ ). Of the 45 live tillers examined from healthy paddocks, $7 \%$ were damaged by $L$. bonariensis larvae with two tillers containing live larvae. In the recovering paddocks the percentage of live $(n=45)$ and dead $(n=20)$ tillers damaged by $L$. bonariensis larvae was $7 \%$ and $80 \%$ respectively. For dead tillers from the very poor paddocks $(n=45), 84 \%$ were damaged.

\section{DISCUSSION}

Clearly from the evidence presented here, substantial levels of larval damage causing visible pasture destruction have been occurring recently in susceptible pastures in January and February both in Waikato and Taranaki. Susceptible pastures, including both diploid L. perenne and L. multiflorum, have low endophyte infection rates, but the tetraploid ryegrasses containing endophytes may also have little resistance to L. bonariensis due to low peramine concentrations (Popay et al. 2003; Popay \& Hume 2011). Because of this, the lower levels of damage recorded in the 2-year-old 'Bealey' paddocks should not be assumed to be due to the higher endophyte levels in these paddocks. Similarly conclusions cannot be drawn from the data presented about the susceptibility of the 'Quartet II' and 'Banquet II' to $L$. bonariensis because only live healthy tillers were tested for endophyte and not those that had been killed by L. bonariensis. It is difficult to determine what level of tiller damage by $L$. bonariensis represents an economic loss. However, it is perhaps reasonable to assume that a $30 \%$ loss of tillers in January followed quite possibly by a similar if not greater loss in February due to the next generation of $L$. bonariensis would cause a significant loss in pasture production at a time of the year when ryegrass is often under climatic stress and there is little regrowth potential. The high number of eggs found in the Italian ryegrass trial in January 2010 indicated a likelihood of further damage to these plants later in the season. Certainly the damage caused by L. bonariensis to 'Bealey' tillers recorded here in late February (Table 1) was very severe and the cumulative damage during the season had resulted in a visibly poor ryegrass cover. The Taranaki samples taken in March also indicated L. bonariensis had been the major cause of recent tiller death.

High levels of adult feeding in the 'Bealey' samples reflect the presence of high adult populations. Of particular interest in these samples, however, were the high numbers of eggs found in paddocks $\mathrm{A} 1$ and $\mathrm{B} 1$ in late February suggesting that these adults were still reproductively active. In the Waikato, $L$. bonariensis populations are thought to undergo two full generations with a partial third generation occurring as a result of early emergent second generation adults becoming reproductive in late February/early March (Barker et al. 1989), 
although most of the second generation adults are thought to enter directly into oligopause (Barker et al. 1988). The high numbers of eggs found suggest that a third generation may also be significant in terms of damage. Even at a low ryegrass tiller density of $2000 / \mathrm{m}^{2}, 13$ eggs/100 tillers could theoretically give rise to a larval population in excess of $200 / \mathrm{m}^{2}$. Given that larvae are capable of destroying many tillers during their development (Barker et al. 1989), considerable larval damage could occur well into March. The larval damage found in dead tillers from the Taranaki farms further demonstrates that L. bonariensis damage can occur late in the season. This was also observed when the senior author visited a property in coastal Taranaki near Manaia in mid March 2009 and found substantial L. bonariensis larval damage and the presence of live larvae.

The monitoring of $L$. bonariensis damage in Waikato and elsewhere over the last 4 years has been the first that has taken place since the late 1990s when samples were taken from one trial at Tokanui, sown in 1996, and one at Ruakura, Hamilton, sown in 1997 (Popay et al. 1999). There was a considerable difference in the amount of larval damage that occurred in these trials with $60 \%$ of tillers damaged in the endophyte-free plots in the Tokanui trial in 1997 but only $12 \%$ the following year in the Ruakura trial. Both trials were less than 1 year old at the time of sampling, which is a vulnerable time for invasion by this pest (Barker et al. 1989; Popay \& Thom 2009). While some of the differences could be attributed to natural variation in populations between years, it seems likely that release of the parasitoid at Ruakura in 1991 and its subsequent establishment was a major factor in the low level of damage at Ruakura in 1998 compared with Tokanui in the previous year where the parasitoid was not present. Similarly, van Vught \& Thom (1998) observed no L. bonariensis larval damage and little change in endophyte levels in endophyte-free perennial ryegrass cv. 'Yatsyn' over 2 years. These authors noted that the parasitoid was well dispersed over the area in 1995, the year prior to establishment of this trial, with $60-90 \%$ parasitism levels recorded.
Changes in endophyte levels in pasture are often a consequence of damage by L. bonariensis (see Hume \& Barker 2005 and references therein). McNeill et al. (2007) also reported generally stable endophyte levels over a 3-year period at four sites in the Wairarapa suggesting the L. bonariensis was not placing substantial selection pressure on these pastures. Notably these dry districts are the very areas where L. bonariensis damage has been particularly severe in the past (e.g. Goldson \& Trought 1980; Francis \& Baird 1989; Kain et al 1977).

Without a thorough investigation of the population dynamics of $L$. bonariensis and its potential to cause damage in the presence of the parasitoid in the Waikato and Taranaki regions there can only be speculation as to the reasons why the parasitoid appears to be unable to prevent severe ryegrass damage at least in some years. Previous research in the Waikato has compared population dynamics pre- and post-release of $M$. hyperodae, concluding that the parasitoid had modified the population dynamics of $L$. bonariensis but that resource availability in terms of endophyte-free tillers remained a major constraint to population increases (Barker \& Addison 2006). These authors found that parasitism reduced natality and subsequent larval populations arising from overwintering adults but asynchrony between emergence of parasitoids and the next generation of adult $L$. bonariensis greatly reduced the influence of M. hyperodae. Phillips et al. (1998) found evidence for similar asynchrony occurring in Canterbury leading to a marked decline in parasitism levels between first and second generations of L. bonariensis (Goldson et al. 2011). A negative relationship between numbers of adult weevils and fecundity has also been identified as a key factor in population dynamics that leads to increased egg laying when adult weevil populations are low (McNeill et al. 1998; Goldson et al. 2011) or tiller resources are limited (Barker et al. 1989). In addition, behavioural adaptations by adult L. bonariensis in response to the presence of the parasitoid that lead to short eruptive oviposition phases when M. hyperodae are not present or are less abundant may also 
significantly lessen the impact of the parasitoid (Barker \& Addison 2006).

In Canterbury, where $M$. hyperodae was first released, Barlow (1993) predicted that peak weevil abundance would be reduced by $50 \%$ within 5 years of release of the parasitoid. Goldson et al. (1998) showed suppression of L. bonariensis egg and larval populations within 6 years of parasitoid release at Lincoln. In addition, only low levels of $L$. bonariensis larval damage $(<10 \%)$ and little change in endophyte status in ryegrass was found in plots monitored between 1997 and 1999 (McNeill et al. 2001). More recently, regular contact with farmers and agronomists has allowed for a general anecdotal assessment of the impacts of $L$. bonariensis on ryegrass productivity in the Canterbury area. The picture that emerges is one of variable persistence and productivity of ryegrass. In some cases, nil-endophyte L. perenne and L. multiflorum research plots have continued to show strong productivity and persistence after 4 years (M.P. Rolston, AgResearch, pers. comm.) while in other areas of Canterbury, significant reductions in productivity under dairy grazing are being recorded after 2-3 years (G.D. Milne, Agricom, pers. comm.). Generally it would seem that the biological control agent fails to suppress weevil damage in highly susceptible 'short rotation' grasses on occasions. Indeed, given the very high vulnerability of nilendophyte L. multiflorum cultivars (e.g. Goldson \& Trought 1980), it is doubtful that M. hyperodae alone could consistently maintain the weevil populations below the damage threshold. These short rotation ryegrasses are now frequently used by dairy farmers for short term increases in pasture production before perennial pastures are established.

The level of percent parasitism at different sites (Barker \& Addison 2006) and between years also varies considerably. Listronotus bonariensis adults have been collected across Canterbury during regular sampling for the white clover pest Sitona lepidus using a blower vac and subsequently dissected to determine levels of parasitism by M. hyperodae (M.R. McNeill, unpublished data). Average percent parasitism in four pastures near Lincoln that were sampled in October 2009 was
$40 \%$ ( $n=60$ weevils) but was only 4\% ( $n=422)$ in three pastures in the same vicinity sampled in October and November the following year (M.R. McNeill, unpublished data).

Other possible factors may reduce the effectiveness of the parasitoid. Listronotus bonariensis is an early coloniser of new pastures (Popay \& Thom 2009; M.R. McNeill, unpublished data) and notably the very high levels of damage reported here were all in ryegrass pastures that were less than 1 year old (Paddocks A \& B, Dairy NZ trial 2009; 'Bealey' Paddocks A1 and B1 2010, Italian ryegrass trial 2011). Parasitism has been shown to severely suppress $L$. bonariensis flight (Goldson et al. 1999), which could lead to differential dispersal of a largely unparasitised cohort of weevils into newly sown pastures as observed in Canterbury (McNeill et al. 2001) and Wairarapa (McNeill et al. 2007). This could well lead to higher levels of damage occurring before a stable population of M. hyperodae has established.

It is now 20 years since $M$. hyperodae was first released. Undoubtedly it has reduced the pest status of L. bonariensis, perhaps to occasional outbreaks. Nevertheless it would be timely to further evaluate its impact now that host and parasitoid will have reached an equilibrium status. Such a study needs to incorporate measurements of L. bonariensis oviposition, larval damage and parasitoid-host generational synchronization and should be conducted throughout New Zealand. This includes the Otago/Southland region where cool temperatures have previously been considered to limit $L$. bonariensis to one complete generation per year (Ferguson et al. 1996) and constrain its impact on pastures (e.g. Eerens et al. 1998). Recently, high adult weevil population densities (up to 400 adults $/ \mathrm{m}^{2}$ ) were measured in south Otago (January and February 2008), and densities over 200 adults/ $\mathrm{m}^{2}$ are now regularly found in central Otago and central Southland (C.M. Ferguson, unpublished data). Ferguson et al. (1996) suggested that L. bonariensis populations were close to being able to complete two generations per year in some areas in Otago and Southland and in favourable years it now seems likely to be doing so. Anecdotal 
evidence suggests that after a recent series of mild winters and warm summers in the early 2000s, $L$. bonariensis is having a more significant impact in this region than before. Historically, farmers were able to utilise endophyte-free ryegrasses but this is no longer the case. Microctonus hyperodae is established in Otago and Southland but in a recent assessment was found in only $35 \%$ of pastures sampled and at levels between September and November 2010 of less than 12\% (C.M. Ferguson, unpublished data).

This paper provides evidence that $L$. bonariensis should not be ignored as a pest in New Zealand. Novel endophytes will continue to be an essential tool, which in conjunction with the parasitoid, will alleviate L. bonariensis damage in perennial ryegrasses. Clearly endophyte and the parasitoid together present a classical example of IPM with ample evidence that the parasitoid has reduced $L$. bonariensis peak populations (J.R. Caradus, Grasslanz Technology Ltd, pers. comm.). However, in the face of changing farm practices, such as widespread use of vulnerable Italian ryegrasses and more frequent pasture renovation, the need to understand the system is probably now more important than ever. This paper highlights the undeniable need for good population dynamics analysis in the presence of $M$. hyperodae, in conjunction with evaluation of seasonal changes in damage in ryegrass pastures.

\section{ACKNOWLEDGEMENTS}

Joanne Jensen and Colleen Podmore are thanked for their assistance with damage assessments. David Hume and Joanne Amyes are acknowledged for providing samples from Taranaki.

\section{REFERENCES}

Barker GM, Prestidge RA, Pottinger RP 1988. Reproductive phenology of Listronotus bonariensis (Kuschel) (Coleoptera: Curculionidae) in northern New Zealand pastures. Bulletin of Entomological Research 78: 659-668.

Barker GM, Pottinger RP, Addison PJ 1989. Population dynamics of Argentine stem weevil (Listronotus bonariensis) in pastures of Waikato, New Zealand. Agriculture, Ecosystems and Environment 26: 79-115.
Barker GM, Addison PJ 2006. Early impact of endoparasitoid Microctonus hyperodae (Hymenoptera: Braconidae) after its establishment in Listronotus bonariensis (Coleoptera: Curculionidae) populations of Northern New Zealand pastures. Journal of Economic Entomology 99: 273-287.

Barlow ND 1993. The role of models in an analytical approach to biological control. In: Prestidge RA ed. Proceedings of the 6th Australasian Conference on Grassland Invertebrate Ecology. AgResearch, Ruakura, New Zealand. Pp. 318-325.

Eerens JPJ, Lucas RJ, Easton HS, White JGH 1998. Influence of the ryegrass endophyte (Neotyphodium lolii) in a cool moist environment. I. Pasture production. New Zealand Journal of Agricultural Research 41: 39-48.

Ferguson CM, Evans AA, Barratt BIP 1996. Phenology of Listronotus bonariensis (Kuschel) (Coleoptera: Curculionidae) in Otago. Proceedings of the 49th New Zealand Plant Protection Conference: 270-274.

Francis SM, Baird DB 1989. Increase in the proportion of endophyte-infected perennial ryegrass plants in overdrilled pastures. New Zealand Journal of Agricultural Research 32: 437-440.

Goldson SL, Trought TET 1980. The effect of Argentine stem weevil on pasture composition in Canterbury. Proceedings of the 33rd New Zealand Weed and Pest Control Conference: 46-48.

Goldson SL, McNeill MR, Proffitt JR, Barker GM, Addison PJ, Barratt BIP, Ferguson CM 1993. Systematic mass rearing and release of Microctonus hyperodae Loan (Hym.: Braconidae, Euphorinae), a parasitoid of the Argentine stem weevil Listronotus bonariensis (Kuschel) (Col.: Curculionidae) and records of its establishment in New Zealand. Entomophaga 38: 527-536.

Goldson SL, Proffitt JR, Baird DB 1998. The bionomics of Listronotus bonariensis (Kuschel) (Coleoptera: Curculionidae) in Canterbury, New Zealand. Bulletin of Entomological Research 88: 415-423. 
Goldson SL, Proffitt JR, Baird, DB 1999. Listronotus bonariensis (Coleoptera: Curculionidae) flight in Canterbury, New Zealand. Bulletin of Entomological Research 89: 423-431.

Goldson SL, Barron MC, Kean JM, Van Koten C 2011. Argentine stem weevil (Listronotus bonariensis, Coleoptera: Curculionidae) population dynamics in Canterbury, New Zealand dryland pasture. Bulletin of Entomological Research 101: 295-303.

Hume DE, Barker DJ 2005. Growth and management of endophytic grasses in pastoral agriculture. In: Roberts CA, West CP, Spiers DE ed. Neotyphodium in Cool-Season Grasses. Blackwell Publishing, Ames, Iowa. Pp. 201-226.

Kain WM, Ritchie IM, Crouchley CG, Smith RG, Atkinson DS 1977. Effects of stem weevil on grazed swards of perennial ryegrasses in Wairarapa and Manawatu. Proceedings of the 30th Weed and Pest Control Conference: 192-197.

McNeill MR, Baird DB, Goldson SL 1998. Evidence of density-dependent oviposition behaviour by Listronotus bonariensis (Coleoptera: Curculionidae) in Canterbury pasture. Bulletin of Entomological Research 88: 527-536.

McNeill MR, Knight TL, Baird DB 2001. Damage potential of Argentine stem weevil in Lincoln dairy pasture: has biological control by $M$. hyperodae altered the balance? Proceedings of the New Zealand Grassland Association 63: 247-254.

McNeill MR, Goldson SL, Proffitt JP, Phillips CB, Addison PJ 2002. A description of the commercial rearing and distribution of Microctonus hyperodae (Hymenoptera: Braconidae) for biological control of Listronotus bonariensis (Kuschel) (Coleoptera: Curculionidae). Biological Control 24: 167-175. McNeill MR, Hume DE, Ashby R, Ashby M, Brandon P, Guscott P, Tosswill R, Barton, R. 2007. Ryegrass production in Wairarapa, New Zealand: is biological control of Argentine stem weevil important? In: Popay AJ, Thom ER ed. Proceedings of the 6th International Symposium on Fungal Endophytes of Grasses Grasslands Research and Practice Series No. 13. Pp. 301-306.
Phillips CB, Proffitt JR, Goldson SL 1998. Potential to enhance the efficacy of Microctonus hyperodae Loan. Proceedings of the 51st New Zealand Plant Protection Conference: 16-22.

Popay AJ, Hume DE, Baltus JG, Latch GCM, Tapper BA, Lyons TB, Cooper BM, Pennell CG, Eerens JPJ, Marshall SL 1999. Field performance of perennial ryegrass (Lolium perenne) infected with toxin-free fungal endophytes (Neotyphodium spp.). In: Woodfield DR, Matthew C ed. Ryegrass endophyte: an essential New Zealand symbiosis. Grassland Research and Practice Series No. 7: 113-122.

Popay AJ, Hume DE, Davis KL, Tapper BA 2003. Interactions between endophyte (Neotyphodium spp.) and ploidy in hybrid and perennial ryegrass cultivars and their effects on Argentine stem weevil (Listronotus bonariensis). New Zealand Journal of Agricultural Research 46: 311-319.

Popay AJ, Thom ER 2009. Endophyte effects on major insect pests in Waikato dairy pasture. Proceedings of the New Zealand Grassland Association 71: 121-126.

Popay AJ, Hume DE 2011. Endophytes improve ryegrass persistence by controlling insects. In: Mercer CF ed. Pasture Persistence. Grassland Research and Practice Series No. 15: 149-156. Prestidge RA, Barker GM, Pottinger RP 1991. The economic cost of Argentine stem weevil in pastures in New Zealand. Proceedings of the 44th New Zealand Weed and Pest Control Conference: 165-170.

Van Vught VT, Thom ER 1998. Survival of endophyte-free perennial ryegrass after autumn spray/drilling in the Waikato. Proceedings of the New Zealand Grassland Association 60: 165-171. 